\title{
DESCRIPTION OF FRIENDSHIP QUALITY IN YOGYAKARTA STUDENTS
}

\author{
Muhamad Hasan Abdillah ${ }^{1}$, Wiwid Dyah Anindita ${ }^{2}$, Sita Permatasari ${ }^{3}$, Bella Rifqi Nabillah ${ }^{4}$, Mujidin ${ }^{5}$ \\ Magister Psikologi Universitas Ahmad Dahlan, Yogyakarta \\ Jalan Pramuka No.42, Umbulharjo, Kota Yogyakarta, 55161 \\ addakhil.abdulloh@gmail.com
}

\begin{abstract}
Abstrak
Persahabatan merupakan fungsi adaptif dari kematangan individu untuk memenuhi sejumlah kebutuhan sosial, kognitif, dan emosional. Tujuan penelitian ini adalah untuk mengetahui makna kualitas persahabatan mahasiswa berdasarkan tahap perkembangan dan jenis kelamin. Subjek pada penelitian ini adalah mahasiswa di Perguruan Tinggi Yogyakarta yaitu sebanyak 200 mahasiswa. Teknik sampling yang digunakan dalam penelitian ini adalah teknik non-probabilitas convenience sampling. Alat pengumpul data berupa kuesioner, dengan analisis konten sebagai analisis datanya. Hasil penelitian ini menunjukkan bahwa pada kelompok remaja akhir laki-laki, terbentuknya persahabatan karena individu merasa dekat dengan sahabatnya; pada kelompok usia remaja akhir perempuan dan dewasa awal perempuan terbentuknya persahabatan karena individu merasa percaya sahabatnya dapat menjadi teman curhat yang mampu memberi solusi; dan pada kelompok usia dewasa awal laki-laki, sifat pengertian dan saling mendukung merupakan alasan terbentuknya kualitas persahabatan. Kesimpulannya adalah alasan terbantuknya kualitas persahabatan berdasarkan tahap perkembangan dan jenis kelamin terdapat perbedaan, namun pada perempuan remaja dan dewasa terdapat persamaan.
\end{abstract}

Kata kunci : jenis kelamin, kualitas persahabatan, tahap perkembangan

\begin{abstract}
Friendship is an adaptive function of individual maturity to fulfill a number of social, cognitive, and emotional needs. The purpose of this study was to determine the meaning of the quality of student friendship based on developmental stages and gender. Subjects in this study were 200 students at the Yogyakarta University. The sampling technique used in this study was a non-probability convenience sampling technique. The data collection tool is a questionnaire, with content analysis as data analysis. The results of this study indicate that in the group of male late adolescents, friendship is formed because individuals feel close to their friends; in the late adolescent age group of women and early adulthood women the formation of friendships because individuals believe that their friends can be confidants who are able to provide solutions; and in the male early adulthood group, understanding and mutual support are the reasons for the quality offriendship. The conclusion is the reasons for the quality offriendship based on developmental stages and gender are differences, but in adolescent and adult women there are similarities.
\end{abstract}

Keywords : gender, quality of friendship, stage of development

\section{Introduction}

Quality of friendship is one of the factors that can influence an individual's trust in close friends or individual relationships with others (Waldrip et al., 2008). The quality of friendship is essential in facilitating complex individual development tasks, such as increasing freedom, organizing tasks for success independently, building and maintaining relationships with others, and presenting positive competition (Fosenburg, 2018). Having quality in friendship is also an adaptive function of self-maturity to fulfil several social, cognitive, and emotional needs (Tipton et al., 2013).

Friendship is formed voluntarily based on preference, attraction, pleasure, and reciprocity. Individuals will choose friends who have similarities with themselves based on gender and developmental stages (Chen et al., 2006). Friendship is said to be of quality when each member plays an active role (Berndt, 2002). The meaning of the quality of friendship of each individual varies based on the stage of development and gender. At the stage of development of adolescence, the late definition of quality of friendship can be in the form of mutual assistance, loyalty, and openness (Baumgartner, 2008). The quality of friendship is more important for adolescent development than the number of friends or the amount of time spent with friends (Ciairano et al., 2007).

Friends can offer support, protection, and closeness (Waldrip et al., 2008). Friends can help individuals more easily adapt to their social 
environment (Magnusson \& Stattin, 2006). Friendship with high quality is very beneficial to the physical and psychological health of individuals. The quality of friendship can also increase the outcome of treatment because of the quality positive encouragement from friends (Salemink et al., 2010).

High-quality friendship has positive strengths in life (Bowker et al., 2010). The quality of friendship can provide many protective factors for individuals. The quality of friendship can also predict psychological, social, and individual academic outcomes (Laursen, 2005). The high quality of friendship can provide closeness, trust, help, and security, and has a positive effect on the process of individual independence (Rabaglietti \& Ciairano, 2008). Individuals with high quality of friendship tend to have higher self-esteem and show fewer symptoms of psychopathology than individuals without quality friendship (Fosenburg, 2018).

The formation of quality friendships is the beginning of the development of adolescence. The quality of friendship is a potential predictor of social perspective-taking skills (Chow et al., 2013). In adolescence, friendship serves as the main source of closeness and support (Chow et al., 2011). Having quality friendships during adolescence can lead to better individual psychological adjustment (Bagwell et al., 2005).Friendship quality is defined as an individual's perception of positive and negative aspects with other individuals. The positive aspects that are intended are such as closeness, trust, assistance and negative aspects such as conflict, competition, dominance (Berndt, 2002). Quality of friendship refers to the extent to which individual friendships with close friends provide psychosocial benefits such as perceptions of positive competence, friendship, assistance and guidance, and friends sharing or telling stories (Weiss \& Smith, 2002).

The quality of friendship is determined by how well individuals with other individuals work together and how individuals with other individuals resolve conflicts (Markievicz et al., 2001). The low quality of friendship can result in unhealthy competition, conflict, and a tendency to dominate others (Burk \& Laursen, 2005). The low quality of friendship can threaten psychological well-being (Sherman et al., 2006). The purpose of this study was to determine the meaning of the quality of student friendship based on the stage of development and gender.

\section{Method}

The subjects in this study were students at the Yogyakarta University with an age group 18-21 years (late adolescents) and the age group of 22-30 years (early adulthood) which numbered 200 students. The selection of subjects in this study using non-probability convenience sampling techniques, namely the process of taking subjects based on ease of access and selection in the surrounding environment.

The data collection tool used in this study was a questionnaire. The contents of the questions in the questionnaire are: "How close are you to your close friends" and "Explain why you trust your close friends". The responses used to answer the first question were: 1) very close, 2) close, 3) not close enough, 5) not close. Meanwhile, the second question is descriptive, which aims to explore a phenomenon.

The data analysis used in this study is content analysis, namely: techniques for categorizing text into contexts of use to make conclusions. Categorization in content analysis is very important as a set of criteria that are integrated around themes or values. The categorization used in content analysis must be very clear which allows other researchers to have the same results with that category.

\section{Result}

Table 1

List of Group

\begin{tabular}{lcc}
\hline Independent Variables & Label & Total \\
\hline \multirow{2}{*}{ Gender } & Men & 65 \\
& Women & 135 \\
Development Stage & Teenagers & 77 \\
& Adult & 123 \\
\hline
\end{tabular}

From a total of 200 undergraduate and postgraduate students grouped by sex and stage of development. Data shows that 65 male students and 135 female students. Grouping based on the stage of development is obtained from 77 late adolescents and 123 early adulthood.

Table 2

Pairing Groups

\begin{tabular}{lcc}
\hline Gender & Development Stage & Total \\
\hline Men & Late Adolescents & 20 \\
Women & Late Adolescents & 57 \\
Men & Early Adult & 45 \\
Women & Early Adult & 79 \\
\hline
\end{tabular}

In table 2 the data is categorized again into four groups, namely: 1) the late adolescent of men is 20 people, 2) the late adolescent of women is 57 people, 3) the early adulthood of men is 45 people, and 4) the early adulthood is 79 . 
Table 3

Description of the Quality of Late Adolescents Male's Friendship

\begin{tabular}{lc}
\hline Categorization & Response Proportion \\
\hline Feel close & 10 \\
Understanding & 6 \\
Place to vent & 2 \\
Help & 2 \\
\hline
\end{tabular}

The first categorization based on the late adolescent group of men obtained information that the reason for forming the quality of friendship in this group is 4, namely: feeling close (with the number of responses of 10 people), understanding (with the number of responses of 6 people), where to tell or confide (with the number of responses two people), and willing to help (with the number of responses of 2 people).

Table 4

Description of the Quality of Late Adolescents Female's Friendship

\begin{tabular}{lc}
\hline Categorization & $\begin{array}{c}\text { Response } \\
\text { Proportion }\end{array}$ \\
\hline Friends confide and believe & 24 \\
Understanding & 19 \\
Kind hearted & 7 \\
Simple & 2 \\
Patient & 1 \\
Do not believed (feel not close) & 4 \\
\hline
\end{tabular}

In the late category of female adolescents, the data found that the reason for the formation of friendship qualities was 6 , namely: friends confiding and trusting (with the number of responses of 24 people), understanding (with 19 responses), kindhearted (with seven responses), simple (with the number of responses of 2 people), patient (with the number of responses of 1 person), and four subjects feel they do not have close friends for reasons of not believing it.

\section{Table 5}

Description of the Quality of Early Adult Male's Friendship

\begin{tabular}{lc}
\hline Categorization & $\begin{array}{c}\text { Response } \\
\text { Proportion }\end{array}$ \\
\hline Understanding and supporting each & 26 \\
other & 15 \\
Believe & 2 \\
For sharing & 2 \\
Close friend & \\
\hline
\end{tabular}

The categorization results in table 5 show that there are four reasons for the quality of friendship, the first is understanding and supporting each other (with the number of responses of 26 people), the two believe (with the number of responses of 15 people), three friends confide (with the number of responses of 2 people), and for close friends (with a total response of 2 people).

Table 6

Description of the Quality of Early Adult Female's Friendship

\begin{tabular}{lc}
\hline \multicolumn{1}{c}{ Categorization } & $\begin{array}{c}\text { Response } \\
\text { Proportion }\end{array}$ \\
\hline Friends confide and trust each other & 27 \\
Willing to help & 19 \\
Understanding & 14 \\
Loyal & 11 \\
Because he is an adult & 1 \\
Do not believe (feel not close) & 6 \\
\hline
\end{tabular}

Based on the categorization of the early female adult groups, data were obtained that there were six reasons for the quality of friendship, these reasons include, friends confide in and trust each other (with 27 responses), willing to help (with 19 responses), understanding (with the number of responses of 14 people), faithful (with the number of responses of 11 people), because of adulthood (with the number of responses of 1 person), and six people who felt not close to their friends on the grounds of not believing.

\section{Discussion}

The quality of friendship contains a number of different explanations between one individual and another, ranging from ordinary relationships to deeper ties (Ciairano et al, 2007). In the late group of adolescents an individual man feels close to his best friend, and this has an impact on the quality of his friendship, the individual tends to be more open with others when he really feels close. The benefit of the individual's openness is that it can reduce stress and have psychological well-being (Sherman et al, 2006). Having understanding friends can also help individuals in completing development tasks, such as assisting independence (Fosenburg, 2018).

Individuals who trust their friends and want to share their stories with them tend to have low stress compared to individuals who only harbor their problems alone. Individuals can discuss the problem to find the best solution, but when individuals trust their friends or friends less, individuals tend to choose to solve the problem alone. Simplicity is also likely to make individuals more comfortable with their friends (Burk \& Laursen, 2005). 
Supporting each other and understanding each other become positive things that improve the quality of individual friendship. Individuals will be more confident with their decisions when the decision is supported by the people closest to believe, and when the decision has been made is not as expected as a friend can play a role as a friend to discuss which can entertain individuals (Waldrip et al., 2008).

Some researchers found that recognition of achievement and social support contributed to friendship commitment. Individuals who have trust in their lives will be more open in receiving assistance and asking for help, but when individuals do not trust their friends, individuals tend to be less open in receiving help from others. Individuals believe only themselves can solve their problems (Martin \& Smith, 2002).

\section{Conclusion}

Based on the results and discussion described above, it can be concluded that each individual interprets the quality of his friendship differently. In the female gender group, the quality of friendship between late adolescents and early adulthood is similar in interpreting the quality of friendship, namely the availability of friends to share stories that can be trusted. However, in the male gender group between late adolescents and early adulthood, the meaning of friendship quality is interpreted differently. In the male, late adolescence group, the formation of friendship bonds is based on emotional ties, while in the early adulthood group, men are based on the availability of social support.

\section{References}

Bagwell, C. L., Bender, S. E., Andreassi, C. L., Kinoshita, T. L., Montarello, S. A., \& Muller, J. G. (2005). Friendship Quality and Perceived Relationship Changes Predict Psychosocial Adjustment in Early Adulthood. Journal of Social and Personal Relationships, 22(2), 235-354. doi: 10.1177/0265407505050945.

Baumgartner, E. (2008). Having Friends in Infancy and in Adolescence: Characteristics, Functions, Risk and Protection Factors. Rassegna di Psicologia, 2(24), 11-30.

Berndt, T. J. (2002). Friendship Quality And Social Development. Current Directions in Psychological Science, 11(1), 7-10. doi: 10.1111/1467-8721.00157.
Bowker, J. C., Spencer, S. V., \& Salvy, S. J. (2010). Examining how Overweight Adolescents Process Social Information: The Significance of Friendship Quality. Journal of Applied Developmental Psychology, 31(3), 231-237. doi: 10.1016/j.appdev.2010.01.001.

Burk, W.J. \& Laursen, B. (2005). Adolescent Perceptions of Friendship and Their Association with Individual Adjustment. International Journal of Behavioral Development, 29(2), 156-164. doi: $10.1080 / 01650250444000342$.

Chen, X., French, D. C., \& Schneider, B. H. (2006). Peer Relationships in Cultural Context. Cambridge: Cambridge University Press.

Chow, C. M., Roelse, H., Buhrmester, D., \& Underwood, M. K. (2011). Transformations in Friend Relationships Across The Transition into Adulthood. California: Sage Publications.

Chow, C. M., Ruhl, H., \& Buhrmester, D. (2013). The Mediating Role of Interpersonal Competence between Adolescents' Empathy and Friendship Quality: A Dyadic Approach. Journal of Adolescence, 36(1), 191-200. doi: 10.1016/j.adolescence.2012.10.004.

Ciairano, S., Rabaglietti, E., Roggero, A., Bonino, S., \& Beyers, W. (2007). Patterns of Adolescent Friendships, Psychological Adjustment and Antisocial Behavior: The Moderating Role of Family Stress and Friendship Reciprocity. International Journal of Behavioral Development, 31 (6), 539-548. doi: 10.1177/0165025407080573.

Fosenburg, S. (2018). Investigating Friendship Qualities in High Ability or Achieving, Typically-Developing, ADHD, and TwiceExceptional Youth (Theses and Dissertations). University of Iowa.

Laursen, B. (2005). Dyadic and Group Perspectives on Close Relationships. International Journal of Behavioral Development, 29(2), 97-100. doi: 10.1080/01650250444000450. 
Magnusson, D., \& Stattin, H. (2006). The Person in Context: A Holistic-Interactionistic Approach. John Wiley \& Sons.

Markievicz, D., Brendgen, M., Markiewicz, D., Doyle, A. B., \& Bukowski, W. M. (2001). The Relations between Friendship Quality, Ranked-Friendship Preference, and Adolescents' Behavior with Their Friends. Merrill-Palmer Quarterly, 47(3), 395-415.

Martin, J. J., \& Smith, K. (2002). Friendship Quality in Youth Disability Sport: Perceptions of A Best Friend. Adapted Physical Activity Quarterly, 19(4), 472-482. doi: 10.1123/apaq.19.4.472.

Rabaglietti, E., \& Ciairano, S. (2008). Quality of Friendship Relationships and Developmental Tasks in Adolescence. Cognition, Brain, Behavior, 12(2), 183-203.

Salemink, E., Van Den Hout, M., \& Kindt, M. (2010). How does Cognitive Bias Modification Affect Anxiety? Mediation Analyses And Experimental Data. Behavioural and Cognitive Psychotherapy, 38(1), 59e66. doi: 10.1017/S1352465809990543.

Sherman, A., Lansford, J., \& Volling, B. (2006). Sibling Relationships And Best Friendships in Young Adulthood: Warmth, Conflict, and Well-Being. Personal Relationships, 13(2), 151-165. doi: 10.1111/j.14756811.2006.00110.x.

Tipton, L. A., Christensen, L., \& Blacher, J. (2013). Friendship Quality in Adolescents with and without an Intellectual Disability. Journal of Applied Research in Intellectual Disabilities, 26(6), 522-532. doi: 10.1111/jar.12051.

Waldrip, A. M., Malcolm, K. T., \& JensenCampbell, L. A. (2008). With A Little Help from Your Friends: The Importance of High-Quality Friendships on Early Adolescent Adjustment. Social Development, 17(4), 832-852. doi: 10.1111/j.1467-9507.2008.00476.x.

Weiss, M. R., \& Smith, A. L. (2002). Friendship Quality in Youth Sport: Relationship to Age, Gender, and Motivation Variables. Journal of Sport and Exercise Psychology, 24(4), 420-437. doi: 10.1123/jsep.24.4.420. 